\title{
Assessment of local pollution influence on the weather and impact on the air quality over subtropical southern Africa
}

\author{
M. Wiston*, M. Montsho \\ Department of Physics, University of Botswana, P/Bag UB00704, Gaborone, Botswana
}

\begin{abstract}
This study discusses the possible role of air pollution and influence on air quality $(A Q)$ and weather over southern Africa. Although it has long been thought that a lotof pollution occurs in the industrialized regions of the Northern Hemisphere, it is quite clear that a vast amount is also generated in the south, and southern Africa contributes significantly. Since industrial revolution, the sub-continent has become one of the major sources of atmospheric emissions mainly from humaninduced activities to meet demand for energy supply and other lifelong needs. The main sources include biomass burning (BB), Aeolian dust and industrial emissions. In the process, trace components generated can negatively impact the atmosphere through aerosol influence on cloud properties and radiation budget, and also affect human health. While anthropogenic emissions are enhanced during winter, natural emissions occur and fluctuate throughout the year. In the case of dust aerosols, they are common over the Kalahari-Namib Desert where dust devils frequently develop overland, keeping the air filled with haze.Commongas pollutants include carbon monoxide (CO), sulphur-and nitrogen oxides(SO $\mathrm{O}_{x}$ and $N O_{x}$ ) from the copper belt(Zambia),Highveld(South Africa), BB-dominated areas and other isolated locations. In particular, a high degree of correlation between weather and pollution in urban source centers and the effect of weather on human health are of special interest. In most cases, humans are exposed to high pollutant levels likely exceeding $A Q$ standards. We propose that more attention should be paid to the rapidly increasing regional pollution levels, as experience from other regions suggest that this can alter climate and $A Q$ composition.
\end{abstract}

Keywords- air pollution, weather, air quality, anthropogenic, human health.

\section{INTRODUCTION}

1.1 Climate and atmospheric chemistry

Southern Africa is characterized by tropical and subtropical climate conditions, and is influenced by the long coastline from the Indian to the Atlantic Oceans. The climate is dominated by a hot-wet (summer) season running from October to March and a cool-dry (winter) season from May to August .Consequently, the subcontinent is a large source of atmospheric pollutants, both natural and anthropogenic (Piketh et al., 1999), with a complex mixture of aerosols ranging from combustion products such as biomass burning (BB), domestic fires, fossil fuels (automobiles and industries/manufacturing) and dust particulates. These emissions can have a direct impact both on the local and global atmospheric pollution, providing large sources of chemical gas- and particle phase into the atmosphere. The negative atmospheric impact due to trace components-referred to as 'air pollution', occurs when harmful substances are introduced into the atmosphere, making the air not comfortable for living. Example can be photochemical smog or dust storms at the earth's surface. Pollution is influenced by species concentration and increases when the rate of emission production is higher than removal processes. Some of the gaseous pollutants -referred to as greenhouse gases (GHGs) can be very harmful in the atmosphere and influence the solar energy budget.

1.2 Pollution, weather and air quality

Pollution can have direct and indirect effects (e.g. acidification, eutrophication, stratospheric ozone depletion) with a wide range of impacts on human health, ecosystems, agriculture and air composition. It can be influenced by several factors: weather (or meteorological) components such as wind over/near an emitting source region, chemical transformations in the air, polluting sources (some sources are stationary while others are mobile) and transport mechanisms. To date, industrialization has impacted on the air quality (AQ) through emission of gases and particles and is also attributed to climate change. The weather and AQ are linked through human health as people can be exposed to higher concentrations of air pollutants and suffer disproportionately from effects of deteriorating AQ.For example, people in large populated cities are often exposed to high levels of pollution and can develop respiratory ailments that hinder their comfortable lives (Schwela, 2012).Aerosol pollution may aggravate heart and lung disease and is associated with heart attacks and 
cardiac arrhythmias, difficulty in breathing (Jhun et al., 2015, and references therein), and makes people more susceptible to respiratory infections.

Just like weather, pollution can change hourly or even daily (USEPA, 2003) from one place to another. AQ pollutants may also have climatic effects; depending on the pollutant, which may be warming or cooling, or a combination of the two (AQEG, 2007). The main cause of air pollution by humans isuse of fossil fuels, power generation, industrial and other domestic operations (e.g. burning of firewood, agricultural activities and waste). Becauseof wide-ranging air pollution problems, governments and other organizations such asthe World Health Organization (WHO) put in placesome governing standards and regulations to monitor the amount of emissions in the atmosphere.AQ guidelines provide an assessment on health effects due to air pollution; threshold limits are set to ensure that the total average concentrations of pollutants do not exceed certain range or levels within which human can be exposed to.

The purpose of this study is to highlight the role of regional pollution, and possible influence on the weather and AQ over southern Africa. We are motivated by the fact that the sub-continent experiences a significant amount of pollution in addition to its varying climatic conditions. The rest of the paper is arranged as follows: section 2 givesan overview of the climate and pollution over southern Africa; section 3 is the methodology and

\section{ITCZ position during wet season}

data acquisition; section 4 focuses on results analysis. Lastly, section 5 is the conclusion on the state of AQ and pollution.

\section{CLIMATE OUTLOOK AND POTENTIAL DRIVERS}

\subsection{Climate pattern}

Southern Africa is prone to frequent droughts and uneven rainfall distribution withtwo distinct seasons (a hot-wet summer and cool dry winter) that significantly determine and control its climate. The most influential factors include the Inter Tropical Convergence Zone (ITCZ), ocean currents, and quasi-stationary high-pressure systems (St. Helena High in the South Atlantic and Mascarene High in the Indian Ocean). Much of the rainfall isreceived between November and February -the period corresponding to the southward displacement of the ITCZ in the Southern Hemisphere (SH) (maximum displacement occurs in January), whereas the dry season occurs when the ITCZ retreats northward (maximum displacement in July).ITCZ annually changes its position on either side of the equator, moving between the Tropics of Cancer and Capricorn (Fig. 1).Its position shifts the belts of planetary winds and pressure systems to the north and to the south annually.

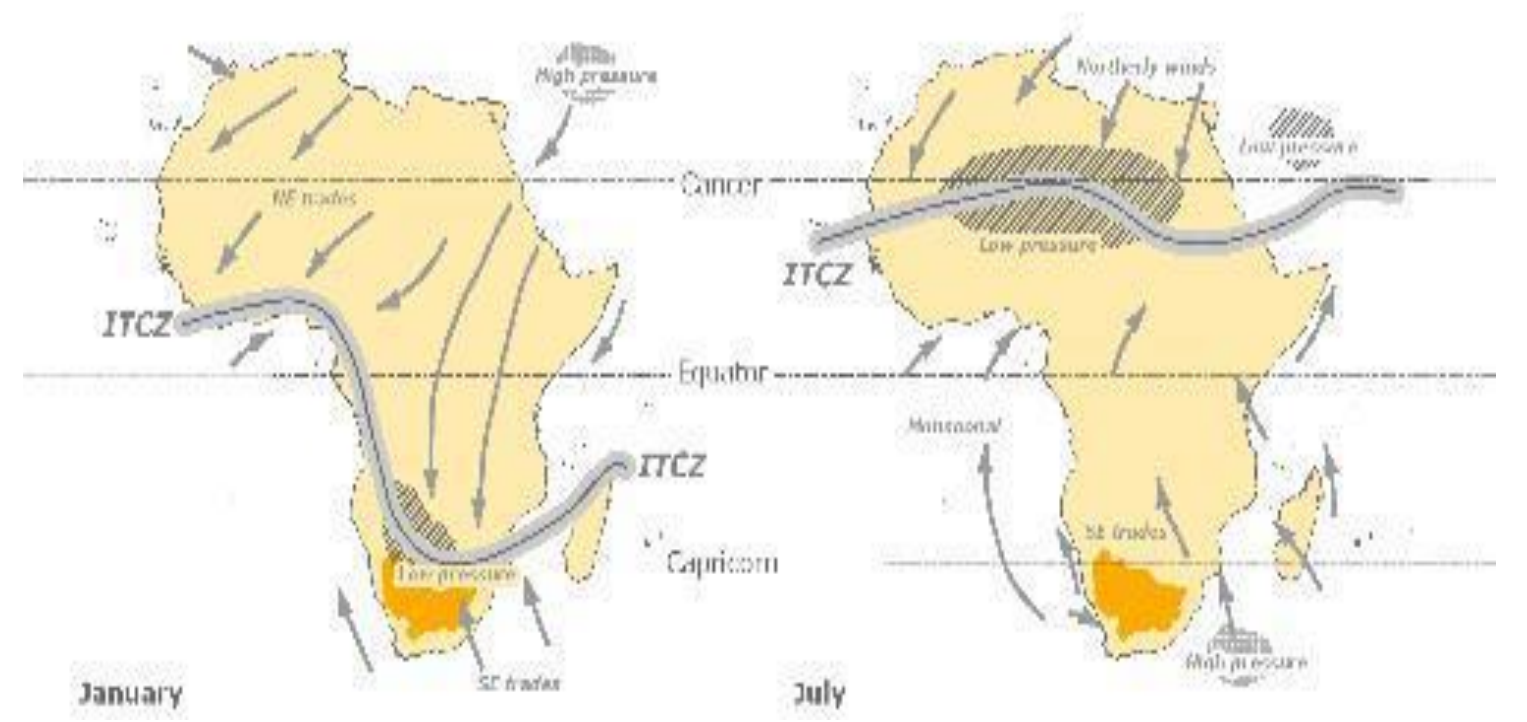

Fig. 1: Southward and northward displacement of the ITCZ between the wet (summer) and dry (winter) seasons in Africa. Source: (http://www.orangesenqurak.com/river/climate/basin/regional.aspx?print $=1$

The South Atlantic and Indian Oceans also play an important roles in the climate. For example, the east coast is influenced by the southward-flowing Mozambique Current(bringing warm water and humid air from the equator, creating a humid warm climate). Contrastingly, the west coast is influenced by the cold Benguela Current from the Atlantic Ocean-which produces a drier climate. There is a strong rainfall gradient over the interior, running from east to west, mainly occurring during summer in the form of thunderstorms. High daily and 
seasonal temperature ranges are also observed as a result of altitude and interior "continental" location (i.e. lack of ocean influences).Total rainfall gradually decreases westward; much of the central and western regions are semi-desert with low and unreliable rainfall. An exception is the southern and western Cape regions of South Africa (this is influenced by maritime conditions and receive winter rainfall as part of a more temperate climate). These parts receive their winter rainfall due to cold fronts rolling from the Atlantic Ocean (Hudson and Jones, 2002) when they are embedded in the westerly wind regimes (Obasi, 2001).

\subsection{Transport climatology}

Air transport climatology over subtropical southern Africa is classified as daily synoptic situations into predominant circulation types. Percentage zonal transport in easterly and westerly directions;total transport is a function of circulation type and frequency, as well asplume dimensions (Tyson et al., 1996a,b).Two major pathways-the Natalplume (eastwards) and the Angolanplume (westwards)are the main carriageways of pollution overland.A typical example is the so-called "river of smoke"outflow from the mainland into the Indian Ocean (Swap et al., 2003). The semi-permanent subtropical continental anticyclones, transient midlatitude ridging anticyclones and mid latitude westerly disturbances produce major transport into the southwestern Indian Ocean along the Natal plume, whereas the quasi-stationary tropical easterly waves result in appreciable transport into the tropical South Atlantic Ocean through the Angolan plume.

Detailed circulation patterns over southern Africa is given by Tyson et al. (1996a)and Garstang et al. (1996), who described for example, four major circulation types occurring with different frequencies:semi-permanent subtropical anticyclones, transient mid-latitude ridging anticyclones, westerly baroclinic disturbances and barotropic quasi-stationary tropical easterly waves. According to the authors, transport in ridging highs and westerly perturbations are much less and occur throughout the year, with a slight tendency peak in spring.Monthly, seasonal and annual mass fluxes over and out of southern Africa form transport fields with substantial aerosol concentrations.

\subsection{Potential climate drivers}

\subsubsection{El Nino southern oscillation}

El Niño-Southern Oscillation (ENSO) is an irregularly periodical variation in winds and sea surface temperatures (SSTs) over the tropical eastern Pacific Ocean, affecting much of the tropics and subtropics. The Southern Oscillation is an accompanying atmospheric component, coupled withSST change. The warming phase(accompanied with high surface pressure) is known as El Niño, while the cooling phase (accompanied with low air surface pressure in the tropical western Pacific) is known as La Niña. The two phasescan each last for several months and their effects vary in intensity.El Niño events often begin in the middle of the year with largescale warming of surface water in the central and eastern equatorial Pacific Ocean and changes in the tropical atmospheric circulation (WMO, 2014).

Generally, El Niñoevents occur every two to seven years and can last up to 18 months; they peak during November-January and decay in the first half of the following year. Strong and moderate El Niño events have a warming effect on the average global surface temperatures (WMO, 2014).Over southern Africa, El Niño usually results in less rain, and normally drought soccur particularly during the critical agricultural period of October to December, and isa major driver to climate variability affecting rainfall (Nicholson and Entekhabi, 1987).For example, taking into account the magnitude of negative impacts in agricultural areas world wide,El Niño of 1992 was classified as themost severe event in 30 years (FAO, 2014). As a result, the economic sector is likely to be affected noting that more than half of the region's population depends on agriculture.

\subsubsection{Sea surface temperatures}

SSTsdefine the predictability of climate in sub-Saharan Africa. This is warm (cool) in the southwest Indian Ocean and cool (warm) in the southeast Indian Ocean; increased (decreased) summer rains may occur over large areas of southeastern Africa. For example, El Niñois the dominant pattern of variability at global scale associated with droughts in the northern and southern hemispheres (Giannini, 2010).SST poles are reversed in sign, decreased precipitation occurs over southeastern Africa as a result of increased low-level divergence or low-level flow and this flow being drier than average.

\subsubsection{Monsoon effects}

Monsoon is traditionally defined as the seasonal reversing wind accompanied with corresponding changes in precipitation. Two main components of the African monsoons are the West African monsoon (prevail during the Northern Hemisphere (NH) summer (JuneSeptember)), and the East African monsoon(common during spring (March-May) and autumn (OctoberDecember)).A combined influence of the Indo-Pacific and the Atlantic Oceans drive the inter-annual and the decadal monsoon variability over these regions.Key features of the West African monsoon are the low level southwesterly flow from the Atlantic Ocean and the ITCZ north of the equator. For example, the West African Sahel is well known for its severe droughts that ravaged the region during the 1970s and 1980s (Nicholson, 2013). East African monsoon is associated with the ITCZ 
moving south of the equator. The land-sea contrast forces the summer northern movement of the ITCZ to be displaced further than it would otherwise be (Bigg, 2003). Long-term precipitation changes from both northern and southern regions of Africa are linked to the monsoon circulations and controlled by precessional variation in summer insolation (Schefub et al., 2005, and references therein). The so-called long rains prevail during spring and the short rains during autumn. The transition (equinox) between seasons brings most rainfall to East Africa.

\subsection{Sources of air pollution}

There are three major air pollution sources defined over Africa:eolian dust, biomass burningand industrial (anthropogenic) emissions (Fig. 2), contributing to the overall global emissions (Piketh and Walton). However, several other common sources also contribute to the overall air pollution over southern Africa, including urbanization, motorization, economic activity, fossil fuel usageand open burning (including vegetative fires and waste burning).

\subsubsection{Biomass burning}

While domestic fuel (e.g. wood and coal) is widely used in most parts of Africa, the largest source of BB comes from vegetation (Swap et al., 2002; 2003).Humaninduced $\mathrm{BB}$ is the main source of aerosols in the $\mathrm{SH}$ (Eck et al., 2003; Torres et al., 2010) contributing over $86 \%$ of the total global emissions of black carbon (soot) -the largest source being the African savannah (Skaeda et al., 2011, and reference therein). BB dominates the chemical atmospheric burden of emissions over most parts of Africa (Crutzen and Andreae, 1990; Liousse et al., 2010; Scholes, et al., 2011), especially during the dry season (Matsueda et al., 2002; Li et al., 2003; Chédin et al., 2005; Magi, 2009). This contributes about $30 \%$ of global burning emissions (Smith et al., 2001; Pikethand Walton, 2004), followed by wind-blown dust and industrialemissions respectively. Savannah fires are the global largest source of BB mostly in the tropics (Andreae et al., 1996; Seinfeld and Pandis, 2006), contributing about $75 \%$ of all related fire emissions (Piketh and Walton, 2004) with more than $60 \%$ of the earth savannah coming from Africa (Li et al., 2003).

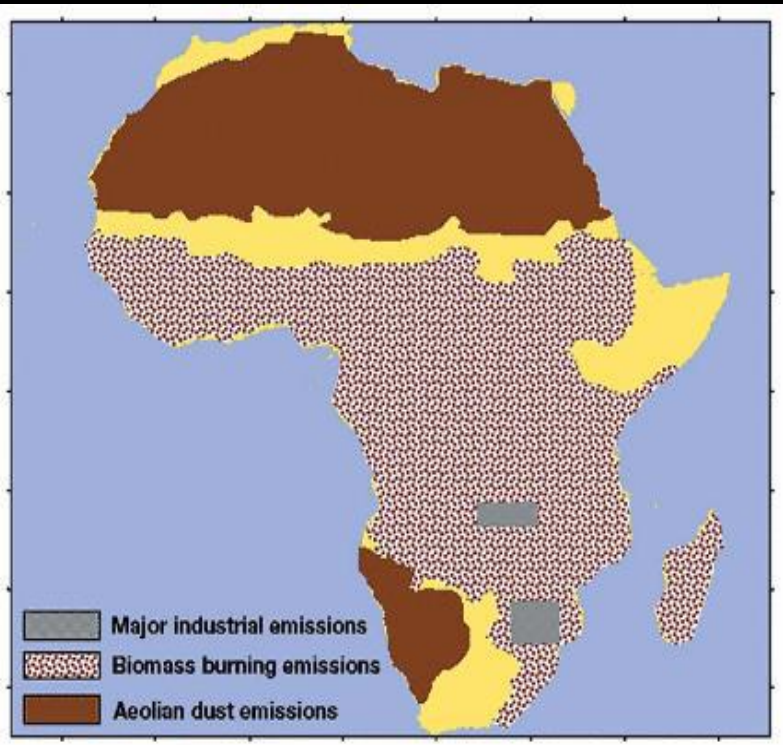

Fig. 2: Major emission sources over Africa, showing dominant source categories. To a lesser extent, other sources do contribute significantly, although not as large as these. (Source: Piketh and Walton, 2004).

The bulk of burning occurs in tropical central Africa (Fig. 3), compared to the much drier north and south extremities. Intense burning reaches its peak around May-Augustand drops towards summer (SeptemberOctober) -marking the beginning of the wet season (Piketh et al., 2002; Tummon et al., 2010, and reference therein).Figure 3 showsBB intensity over Africa in 2005, indicating the seasonal fire patterns. The images are based on fires detected by the Moderate Resolution Imaging Spectroradiometer (MODIS) from the National Aeronautics and Space Administration (NASA)'s Terra and Aqua satellites. Each image is a 10day composite of fire detections (marked in red and yellow); the series include images from every other 10day period from 1 January through June to 18 August 2005. Red colour indicates locations with few fires detectedduring the 10-day period whereas yellow indicates many fires detected over an area.

\subsubsection{Industrial/Anthropogenic emissions}

The most significant industrial trace gases emitted over southern Africa include sulphur- and nitrogen oxides $\left(\mathrm{SO}_{\mathrm{x}}\right.$ and $\mathrm{NO}_{\mathrm{x}}$ ), carbon monoxide (CO)and other gas compounds. Most of the gas emissions are concentrated over the Mpumalanga highveld (South Africa), the copper-belt (Zambia) and other isolated points such as theBamangwato Concessions Limited (BCL) mine in Botswana.However, BCL is currently not operating, after being placed under liquidation in 2016. Also, there is a large amount of aerosol pollution generated from various source sectors such as cement and timber processing, construction/manufacturing sites, mining and other operations across the sub-continent. 
Some studies(e.g. Benkovitz et al., 1996; Meter et al., 1999) had proposed that emissions from industrial emissions contributed up to 2,24 Mt per annum.For example, it was estimated that the spatial distribution contributed a total of $1.1 \mathrm{Mt}$ of sulphur emitted into the regional atmosphere annually (Sivertsen et al. (1995). Out of this, $66 \%$ was said to come from South Africa alone (Piketh et al., 1999), from which about $90 \%$ was from the Mpumalanga's highveld area (Sivertsen et al., 1995; Wells et al., 1996). South Africais the most industrialized country in southern Africa (Piketh and Walton, 2004), and one of the world's most carbon intensive countries with per capita emissions higher than most European countries (DEA, 2014).The $\mathrm{Cu}-\mathrm{Ni}$ and smelter plantin Botswana has been one significant source of sulphur emissions (before its closure), accounting for $0.19 \mathrm{Mty}^{-1}$. During winter(when anthropogenic emissions increase) it would be expected that industrial and BB emissions become well mixed over land.

\subsubsection{Aeolian dust}

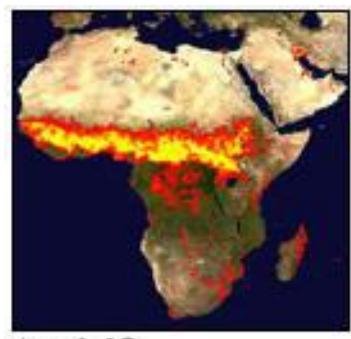

Jan $1-10$

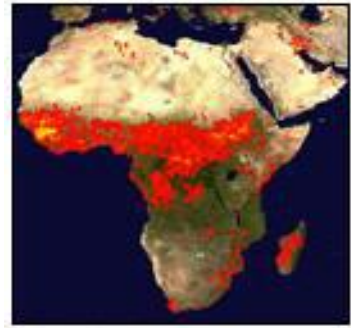

Mar 22-31

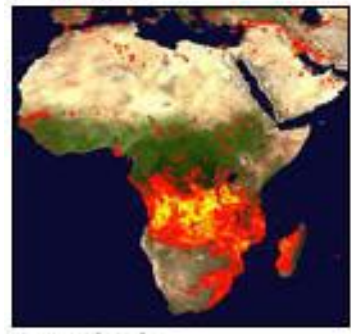

Jun $10-19$

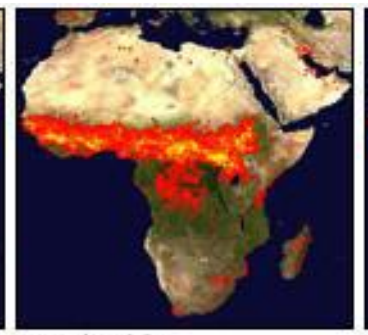

Jan $21-30$

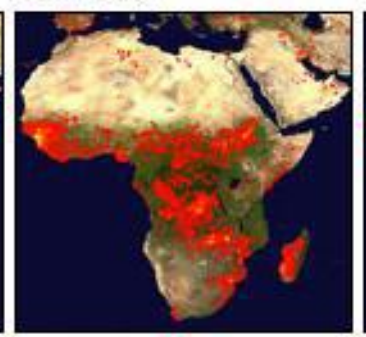

Apr 11-20

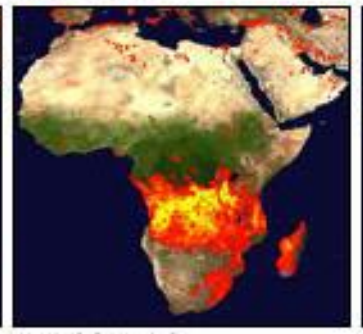

Jun 30-Jul 9
Desert dust is particularly the main aerosol component in many arid and semi-arid regions (e.g. Sahara and subSaharan Africa: Zakey et al., 2006). These emissions (emitted through suspension, saltation and creeping processes) occur mostly in episodic events determined by threshold near-surface wind conditions. Naturally, dust aerosols originate from the local bare soils (devoid of vegetation or grass). Dust can be a regional scale climatic forcing agent when vast dust plumes are suspended into the atmosphere.This is particularly true for regions wheredust plumes are suspended into the atmosphere andtransported over hundreds to thousands of kilometers. Large amounts of mineral dust can be transported across, which in combination with other emissions lead to persistent haze because of lack of wet removal (Knippertz et al., 2015). The fine dust particles can be lifted up to higher altitudes and transported over long distances away from their source regions. Their effects can be felt not only locally, but also at places/regions far awayfrom their source regions (Zakey et al., 2006).
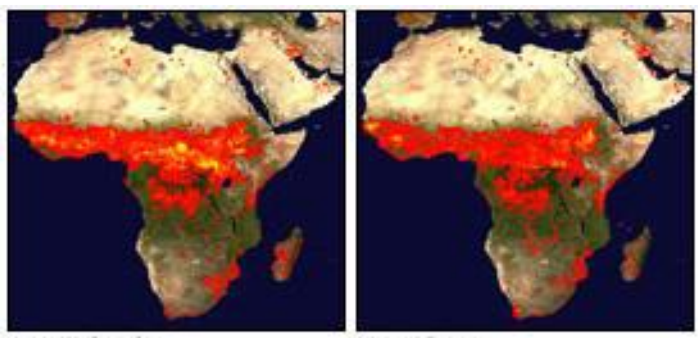

Feb 10-19

Mar 2-11
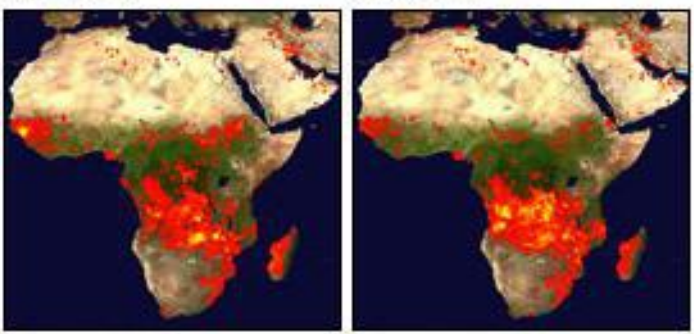

May 1-10

May 21-30
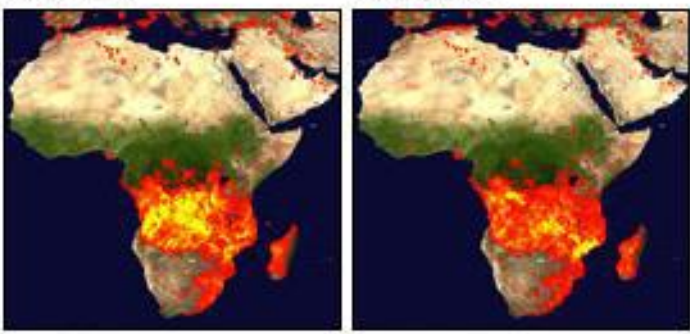

Aug 9-18

Fig. 3: Biomass burning intensities between 1 January and 18 August 2005; the highest burning intensities occur from May to August (dry season). Source: (https://earthobservatory.nasa.gov/IOTD//view.php?id=5800).

Africa has vast tracks of desert dust aerosol emissions, mainly from the Sahara Desert (North Africa) and the southwest coast of Namib Desert (southern Africa).Strong winds known as "berg winds" (mountain winds) can loft plumes of dust directly out into the Atlantic Ocean depending on the wind speed and direction (Piketh and Walton, 2004).

\subsubsection{Automobiles and othersources}

The rapid, unplanned and uncoordinated town/city growth has negatively impacted population centers in different regions, resulting in many people moving between the 
city centers to urban area outskirts. High population increases together with pollution levels seriously compromise existing transportation systems and significantly increase the challenge of creating future transportation systems (Road management, 1998).Populationgrowth naturallyinfluences car ownership (privately owned).For example, motor vehicle fleets have recently increased in countries such as Botswana and Zimbabwe (Simukanga et al., 2003), due to imported second-hand vehicles no longer meetingcertain standards intheir countries of origin (Wiston, 2017). These imported vehicles are not properly maintained or checked on how they emit pollutants. This increase in number of vehicles results in an increase in fuel consumption.For example, in city centers where traffic congestion can be responsible for $90-95 \%$ of $\mathrm{CO}$ and 60 $70 \%$ of $\mathrm{NO}_{\mathrm{x}}\left(\right.$ Schwela, 2004). $\mathrm{NO}_{\mathrm{x}}\left(\right.$ where $\mathrm{NO}_{\mathrm{x}}=\mathrm{NO}+$ $\mathrm{NO}_{2}$ ) and hydrocarbons pose a major threat to human health and natural resources (Chanda, 2014). These emissions can contribute to photochemical smog, especially in areas experiencing high traffic density such as central business districts (CBDs). The escalating emission rates are also exacerbated by road congestions, poor vehicle maintenance and high average age of the vehicle fleet.

\subsection{Weather, pollution and air quality}

Air pollution has a significant impact on climate and air composition in many ways. For example, GHGs in the atmosphere can trap heat and contribute to global warming. These gases(e.g. carbon dioxide $\left(\mathrm{CO}_{2}\right)$, ozone $\left(\mathrm{O}_{3}\right)$, methane $\left(\mathrm{CH}_{4}\right)$ )once emitted can remain in the atmosphere for decades to centuries. They absorb and emit radiation within the thermal infrared range. Their concentrations can become well-mixed throughout the global atmosphere depending on the prevailing meteorology, regardless of location of emission source and their effects on climate could be long lasting (USEPA, 2009). Also, particles such as black carbon (BC) and nitrates absorb and scatter radiation, therefore affecting the radiative balance. Similarly, the weather can affect air pollution; it can either raise the development of pollution or stop its development depending on the environmental conditions such as in tropical areas where precipitation often occurs. It is more likely that pollutants would be washed out by precipitation (Pachauri, 2007). Changes in atmospheric gas- and aerosol concentrations, land cover and solar radiation alter the energy balance of the climate system (IPCC, 2007) and are drivers of climate change. The changes in energy balance due to these factors are expressed as radiative forcing-a process used to compare the warming or cooling influence on global climate.
In principle, any pollutant that contributes to local/regional pollution and act as a radiative forcing agent or changes solar distribution may potentially produce a linkage between $\mathrm{AQ}$ and climate change (AQEG, 2007). Changes in weather and climate can affect AQ as different areas experiencevarying climatic conditions and different pollutant concentrations. For example sunshine, rain, precipitation and wind can affect the amount of air pollution in an area, leading pollution washout, heat absorption or pressure variation in the atmosphere. Photo-energy makes some pollutants undergo chemical reactions in the atmosphere; higher temperatures and strong winds can also speed up chemical reactions in the atmosphere, rain washes out water-soluble pollutants. The wind can carry air contaminants away from their source, anddistribute themto other areas. Higher (strong) winds resultin fastdispersal of contaminants and increasetheirmixing in the atmosphere; the boundary layer may also change due to mixing.

\section{METHODOLOGY}

\subsection{Data acquisition and sources}

Meteorological and chemical data is obtained from several databases:National Oceanic and Atmospheric Administration (NOAA) (www.esrl.noaa.gov/psd/data/composites/hour./), the geostationary Dundee Satellite (http://www.sat.dundee.ac.uk/satellites.html) and the NASA's archived Giovanni (www.giovanni.gsfc.nasa.gov/Giovanni/service)forwind field, temperature, precipitation, clouds and chemical emissions over the study domain. NASA's Giovanni (Geospatial Interactive Online Visualization and Analysis Infrastructure) is a web-based application developed by the Goddard Earth Sciences Data and Information Services Center (GES-DISC)to provide simple and intuitive way to visualize, analyze, and access vast amounts of Earth science remote sensing data. Satellites provide quantitative data, images (maps) showing spatial distribution and pollutant concentration over an area.

We focus on the summer (Nov-Jan) and winter (MayJuly) seasons over the 10-year period (2000-2010) looking at the trend of pollutants and climatology over the sub-continent. Specifically, we look at emission scenarios in 2000, 2005 and 2010 at 5-day intervals -both surface and temporal distributions. Pollution patterns are then discussed in relation to the meteorological parameters over the same period and locations in order to understand how the weather interacts with the chemistry. For example, the period 2000-2010experienced more constructions and industrial activities over southern Africa. This period also falls within the time during which many African countries were preparing for the world 
soccer tournament (2010 World Cup), which took place between June and July 2010 in South Africa. Most activities were aimed at attracting tourists and investors to the African continent.

\section{RESULTS AND DISCUSSION}

We present and discuss outputs for meteorological and chemical variables over the domain as highlighted above. First we start with the meteorology before the chemistry and later look at their interactions. Because the chemistry is driven by the meteorology one needs to first understand and appreciate the dynamics in the meteorology.

4.1 Meteorology (weather pattern)

(a) Wind speed and direction
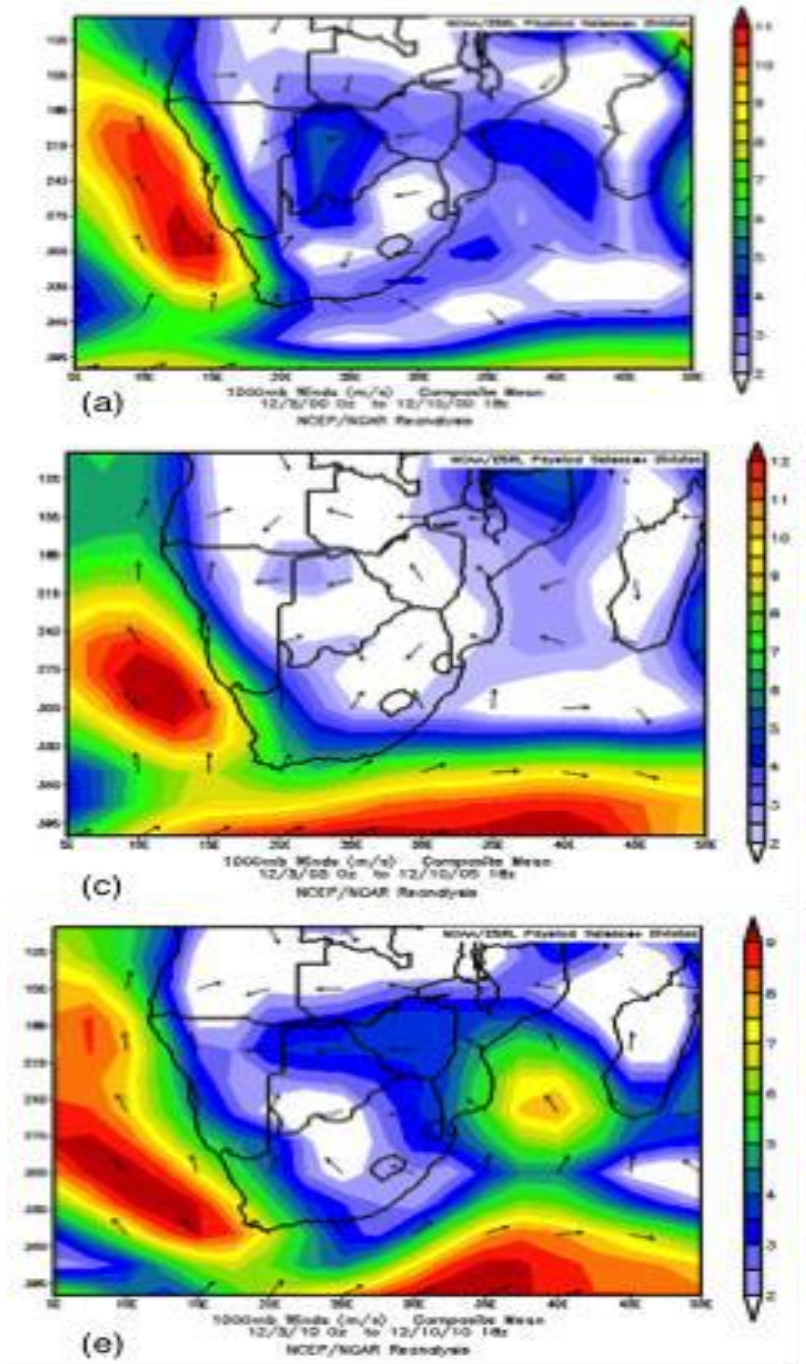

Winds are particularly important in the chemistry because of their direct influence on transport, atmospheric stability and mixing of pollution. For example, wind speed determines how quickly pollutants mix with the surrounding air and how fast they move away from their sources. This is important for any weather-pollution studies because, by knowing the wind field,one can describe transport patterns and possible influence on/by pollution. Figure 4 shows near-surface (1000-mb) mean wind field, from the NOAA's Earth Systems Research Laboratory (ESRL) database between 05-10 December and 05-10 June in 2000, 2005and 2010 respectively.The left panels represent summer while the right panels represent winter.

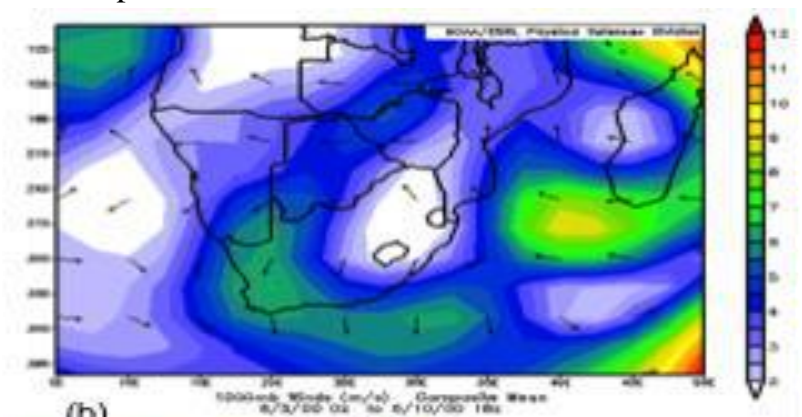

(b)

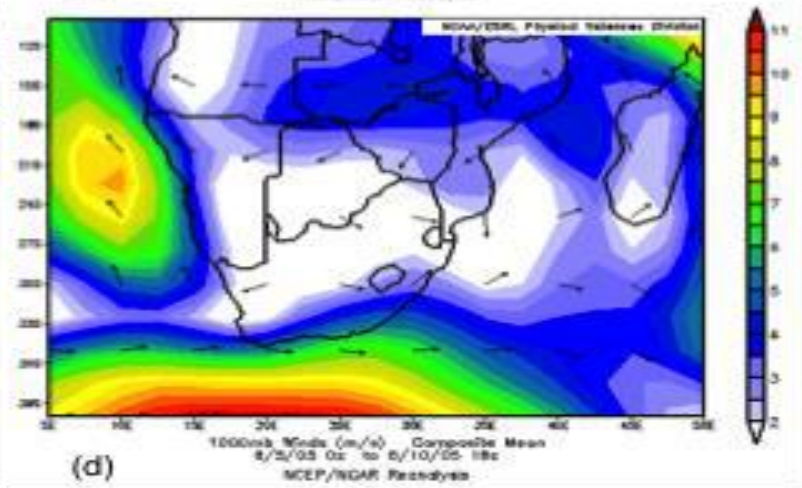

(d)

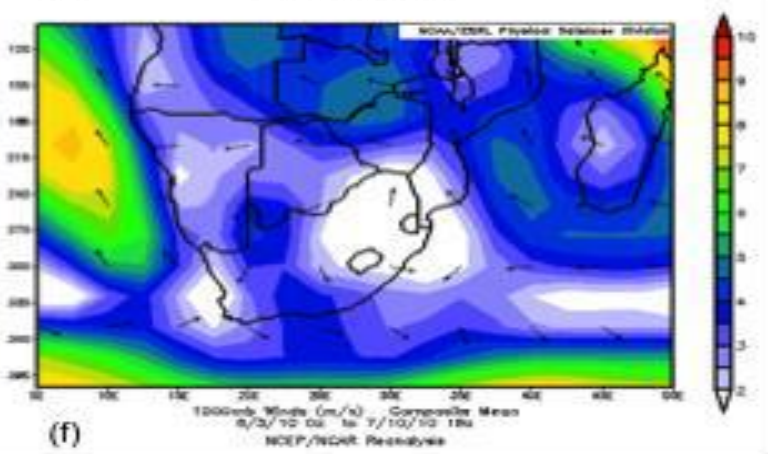

Fig 4: 1000-mb wind field during summer and winter in 2000 ((a), (b)); 2005 ((c), (d)); 2010((e), (f)) respectively. Output between 05-10 December and June. Arrows indicate wind direction and scales are colour-coded in terms of wind speed.Source: NCEP/NCAR reanalysis observation.

High wind speeds occur in summer especially over the Atlantic and southern part of the domain. For example, summer speed reach over $11 \mathrm{~m} / \mathrm{s}$ in 2000 and $9 \mathrm{~m} / \mathrm{s}$ in winter, south of Madagascar (Fig. 4(a) and (b)). The winds were mostly northeasterly coming from the Indian
Ocean during summer and strong southerly over the west coast of Namibia, whereas in winter they are mostly easterly and northeasterly in the south. The winter of 2005 had relatively low winds than in summer. Summer maxima reach over $12 \mathrm{~m} / \mathrm{s}$ while winter maxima was 
below $11 \mathrm{~m} / \mathrm{s}$. The pattern is almost similar but more clearly defined in 2010 and the summer of 2005 (Fig. $4(\mathrm{c}-\mathrm{f}))$. This indicates the possible direction of pollution transport, especially in the south where winds are westerly. The pattern also shows that the center of strong winds over the Atlantic Ocean slightly moved away from the sub-continent (southeasterly) between 2000 and 2010 during summer, and a new center developed from the east.

\section{(b) Temperature}

Next we show mean temperature distribution (Fig. 5). Again there are similar patterns in temperature as observed for wind. Summer temperatures were higher over the Kalahari, extending to the northeastern part of Namibia and central Zambia-Malawi, reaching 309K while most of the landmass experienced temperatures between $290 \mathrm{~K}$ and $306 \mathrm{~K}$. Winter had the temperature maximum of just over $300 \mathrm{~K}$ over central Angola while the rest of the sub-continent remained cooler, especially over the oceans. Higher temperatures were observed in the summer of 2005 (Fig. 5(c)) reaching over 307K over
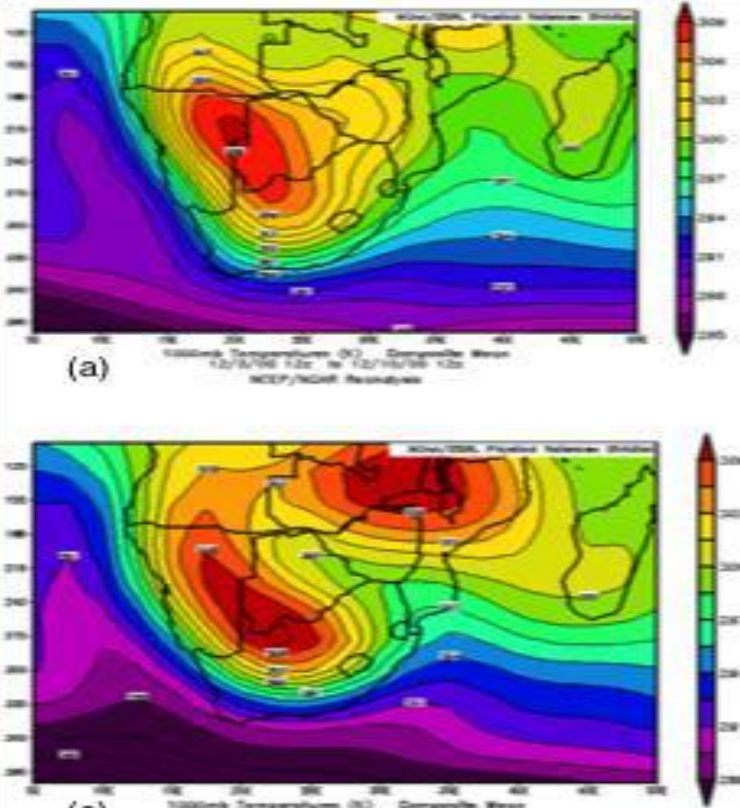

(c)
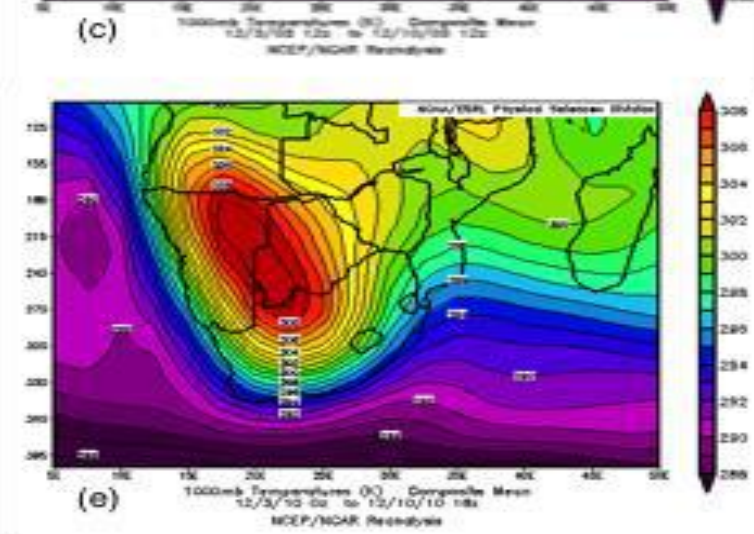

Zambia and the southern part of Kalahari, while winter temperatures (Fig 5(d))had a maximum of just above 300 Kover Angola and average of $250 \mathrm{~K}$ over much of the southern part. The summer of 2010 (Fig. 5(e)) had its temperature maxima over Botswana-Namibia, while winter had maximum temperature over northern Angola/southern Democratic Republic of Congo (DRC).

\section{c) Precipitation and clouds}

We also show accumulated precipitation (Fig.6), where we observe higher precipitation during summer (maximum of $40 \mathrm{~kg} / \mathrm{m}^{2}$ ) over southern and northeastern Mozambique and west of Angola. Lowest rainfall (below $15 \mathrm{~kg} / \mathrm{m}^{2}$ ) was experienced over the western part of South Africa and southwestern tip of Namibia. The highest rainfall in winter was $32 \mathrm{~kg} / \mathrm{m}^{2}$ over eastern Mozambique coast with low rainfall across Lesotho and southern parts of South Africa (Fig. 6 (b)). More precipitation occurred over the Mozambique coast (Fig. 6(c)), reachingwell over $45 \mathrm{~kg} / \mathrm{m}^{2}$ whereas winter was mostly dry, with the highest rainfall around $17 \mathrm{~kg} / \mathrm{m}^{2}$ over the Indian Ocean and northern part of Mozambique coast.
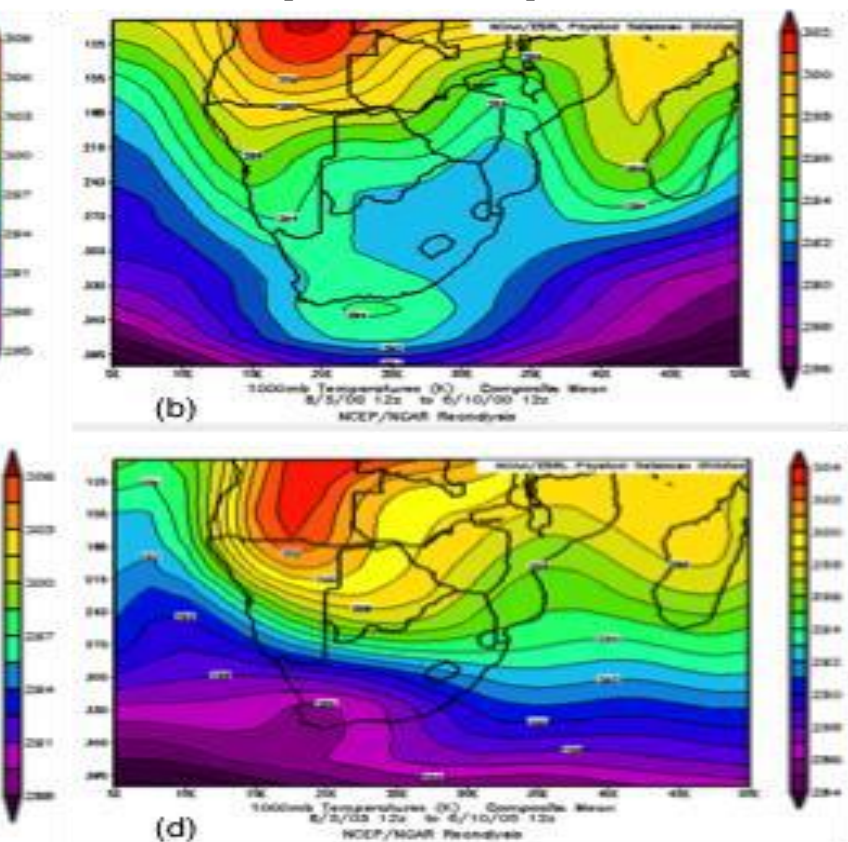

(d)

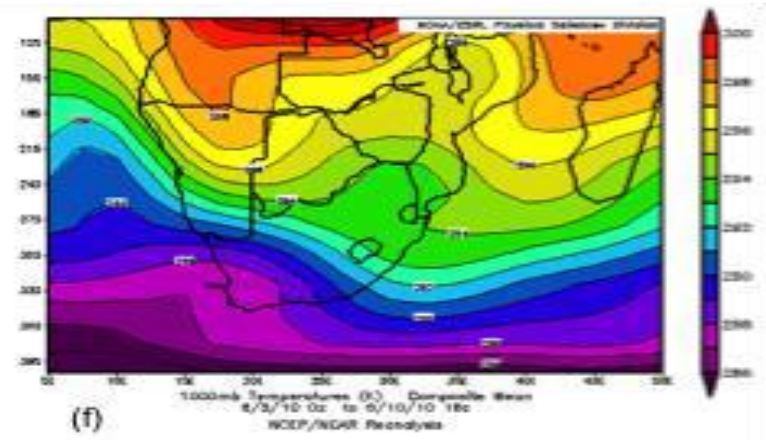

Fig 5: 1000-mb temperature during summer and winter in 2000 ((a), (b); 2005 ((c), (d)); 2010 ((e), (f)) respectively. Contours indicate temperature variation and scales are colour-coded in terms of temperature range.Output between $05-10$ December and June. Source: NCEP/NCAR reanalysis observation. 
The summer of 2010 also shows precipitation almost over the same location as in 2005(about $40 \mathrm{~kg} / \mathrm{m}^{2}$ between Mozambique-Madagascar), while the winter was drier over much of the landmass. Overall, it appears that summers accumulate more precipitation over the Indian Ocean and west of Angola.

Clouds are one of the important factors in weather, because they are directly linked to pollution through

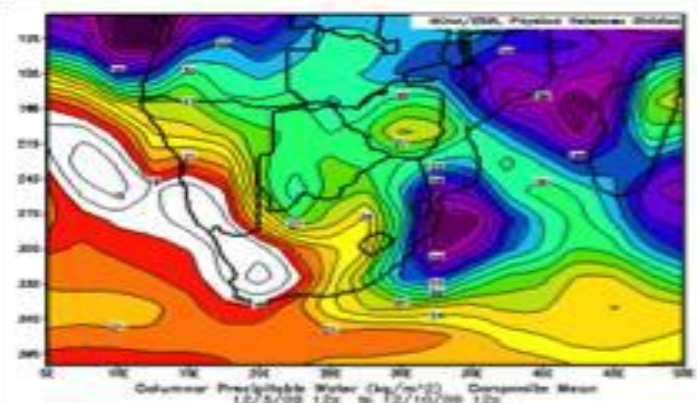

(a)

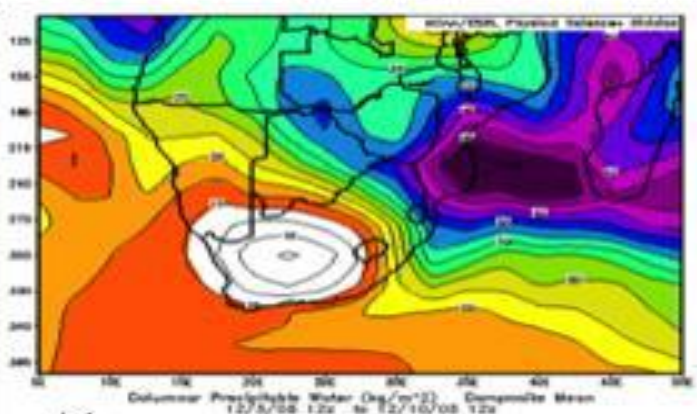

(c)

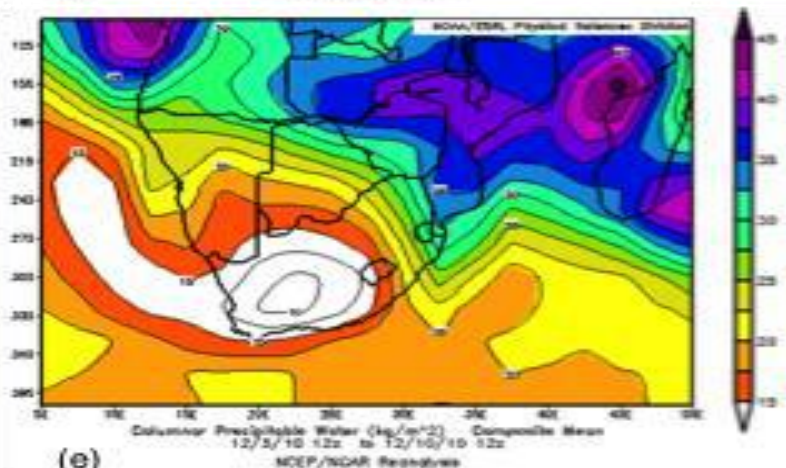

aerosols. To better understand aerosol-cloud effects, one needs to know whether there are clouds over the domain and where they are located. Figure 7 shows satellite imagery (from the Dundee satellite station) in 2005 and 2010.
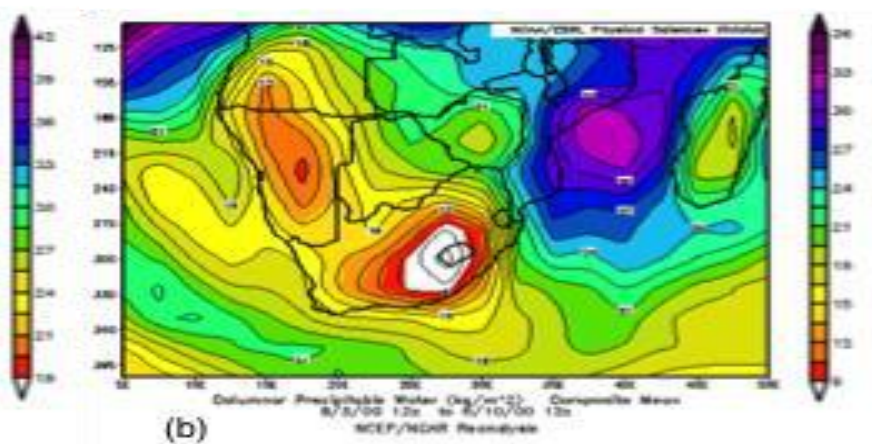

(b)

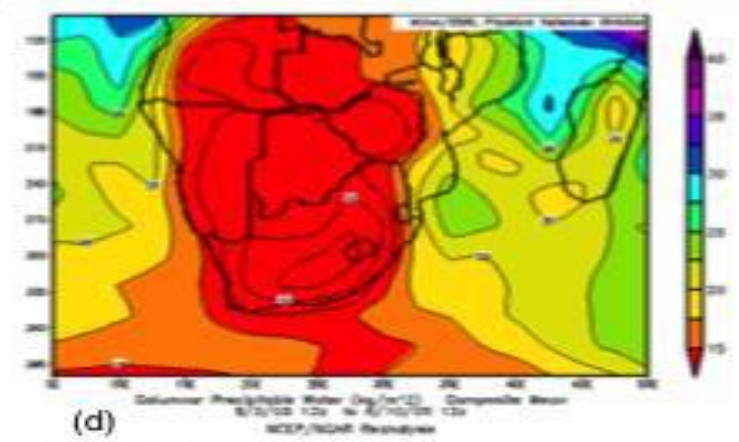

(d)

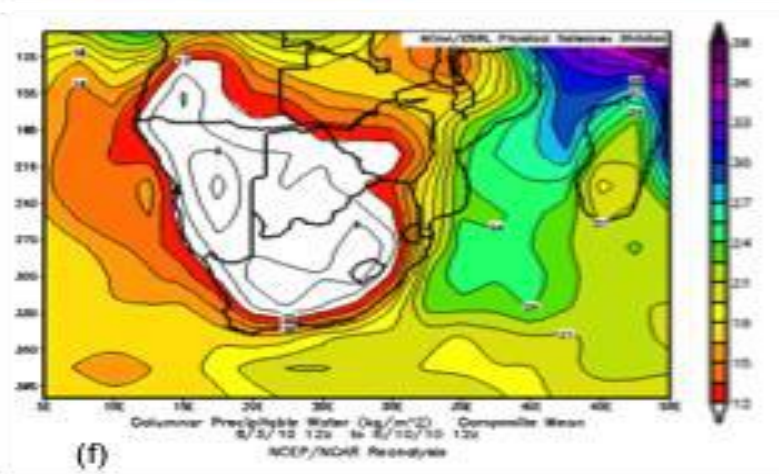

Fig 6: 1000-mb accumulated precipitation between summer and winter in 2000 ((a), (b); 2005 ((c), (d)); $2010((e)$, (f)) respectively. Contours indicate precipitation variability, scales are colour-coded in terms of precipitation maximum. Output between 05-10 December and June. Source: NCEP/NCAR reanalysis observation.

Satellites provide estimates of area coverage of clouds by the cloud-top temperature and the column-integrated optical thickness. They maintain an up-to-date archive of images covering the globe. The summer of 2005 (Fig.7(a)) had substantial cloud cover, mostly over the central-towards-east and some cloud patches over the Atlantic Ocean. Much of the domain was clear during winter, with few cloud bands over the oceans. Similarly, the summer of 2010 (Fig.7(c)) had more clouds concentrated mostly over the northern part of southern Africa and marine environments. While the winter was similar to that of 2005, few cloud patches appear over the South Atlantic Ocean. 


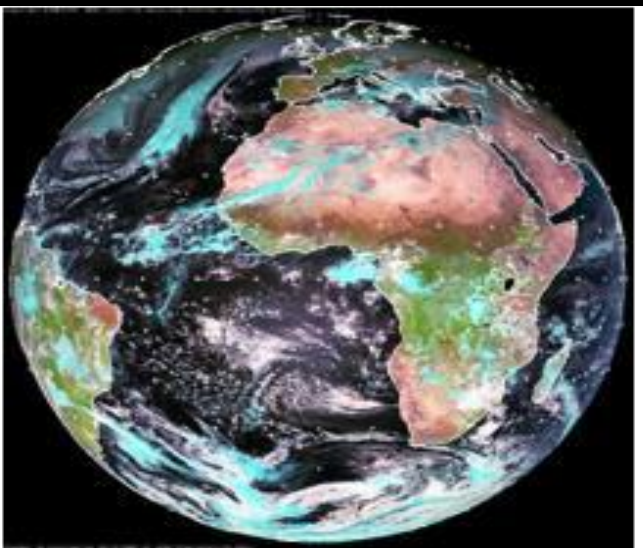

(a)

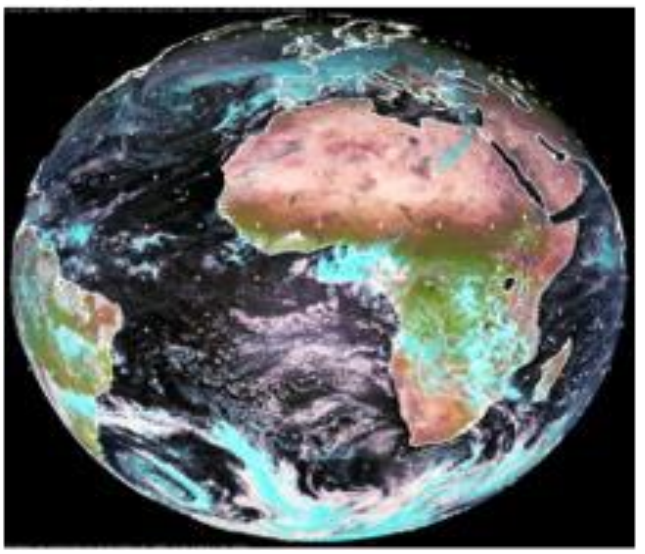

(c)

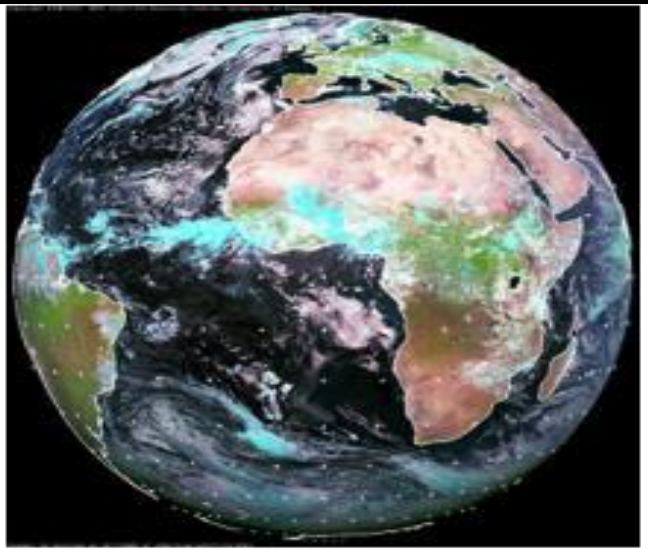

(b)

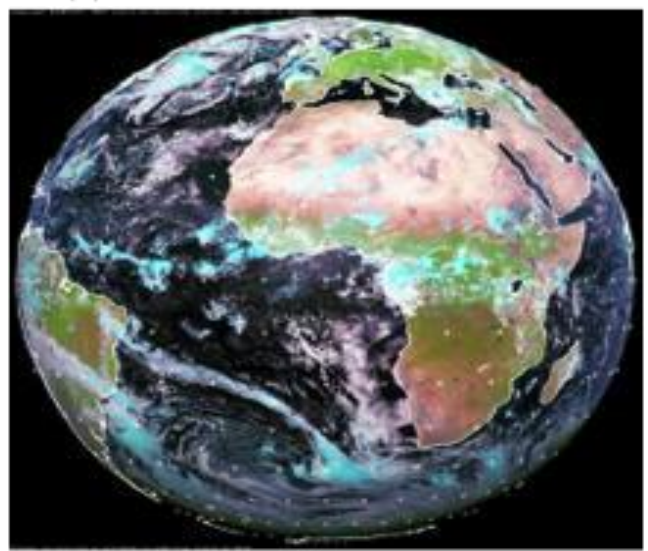

(d)

Fig 7: Accumulated column integrated clouds over Africa between summer and winter in 2005 ((a), (b) and 2010 ((c), (d)) respectively. Output between 05-10 December and June.Source: Meteosat infrared satellite images (http://www.sat.dundee.ac.uk/).

\subsection{Emissions (pollution)}

\section{(a) Dust}

Now we look atchemical emissions, focusing ondust (aerosols), $\mathrm{NO}_{\mathrm{x}}, \mathrm{SO}_{2}$ and $\mathrm{CO}$ (gases). These are primary pollutants(i.e. directly from the sources) and are shown for the same time periods as the meteorology discussed above for consistency.Figure 8 shows dust concentration obtained from the NASA's Giovanni database.More dustappearsduring summer along the southwest coast (Namib Desert) throughout the years, and a significant amount over DRC in 2000. One also notices an increase in the east along the Kenyan coast during the winter of 2005 (Fig. 8(d)). The winter of 2010 shows dust over the Atlantic, along Namibia-Angola coasts. Dust emissions are generally common along the west (Kalahari-Namib Desert) than other geographical locations. However, that is so expected for this part of the globe because region is drier than its eastern counterpart -the so-called Kalahari Transect (Shughart et al., 2004). 

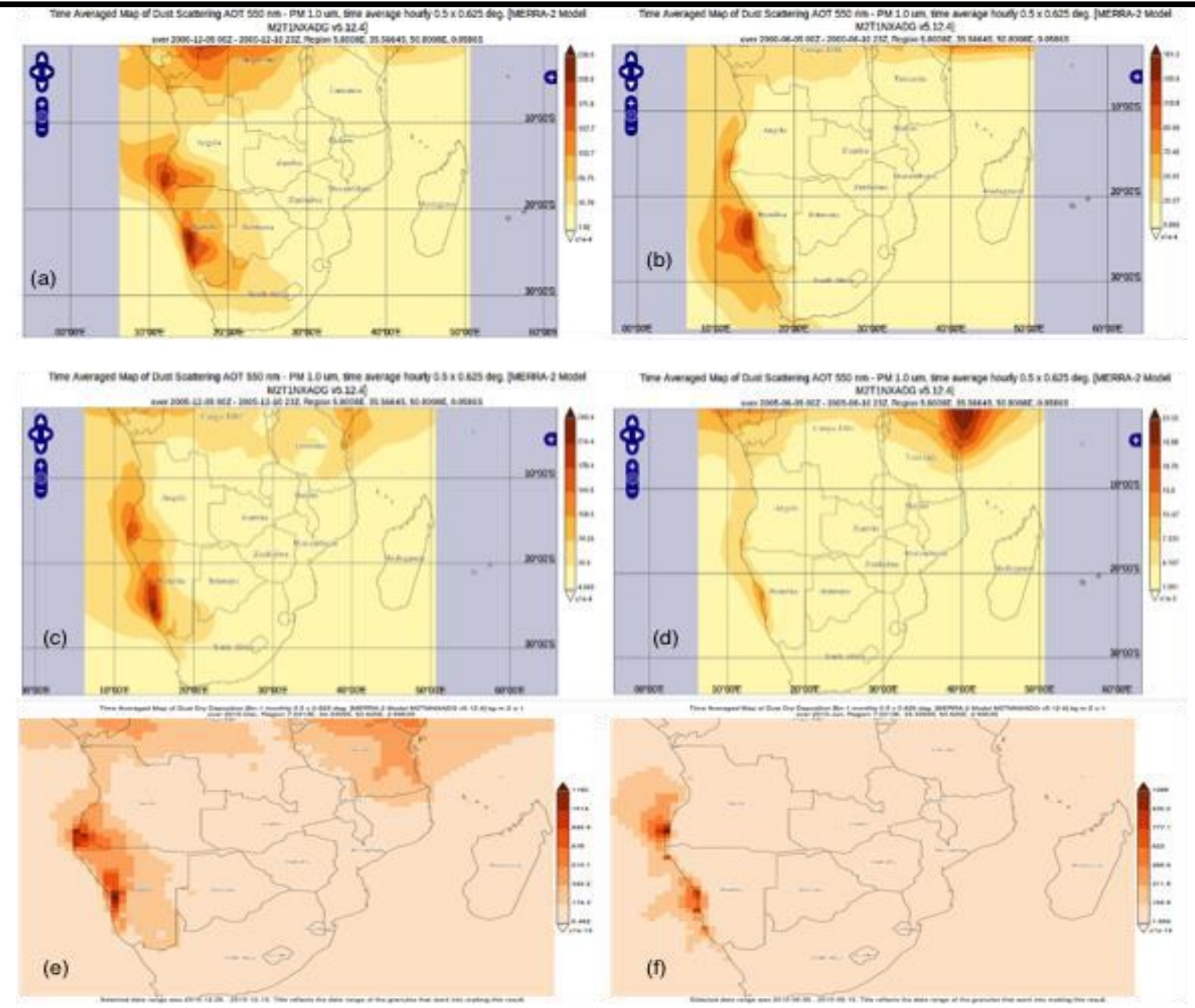

Fig. 8: Dust concentrations between (a) summer and (b) winter respectively. Contours indicate increasing particle concentration and scales colour-coded in terms of concentration maxima. Source: MODIS onboard the Aqua satellite measurement (http://giovanni.gsfc.nasa.gov/giovanni/).

\section{(b) Sulphur and nitrogen oxides}

Next we show the spatial distribution for $\mathrm{SO}_{2}$ (Fig. 9), from the same database. As expected, more $\mathrm{SO}_{2}$ is observed over/around industrial locations highlighted earlier (see Sect. 2.4). $\mathrm{SO}_{2}$ is an air pollutant often associated with combustion in power generation, fossil fuel refining and ore smelting (Zunckel, et al., 2000) such as the mines. About 1.8 million tons or more of $\mathrm{SO}_{2}$ is emitted from electrical generation annually. For example, the annual ambient $\mathrm{SO}_{2}$ concentration from South Africa, on average, is said to approach $20 \mathrm{ppb}$ guideline (WHO; Kgabi, 2012). These are quite clear in the southern partwith more industrial operations. Typical locations include the copper-belt, highveld and other isolated small plants. 
(a)

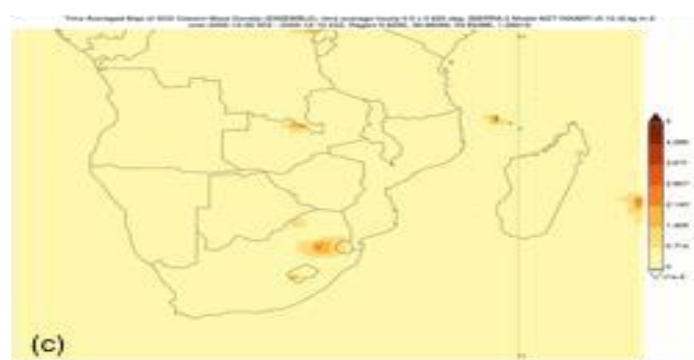

(b)

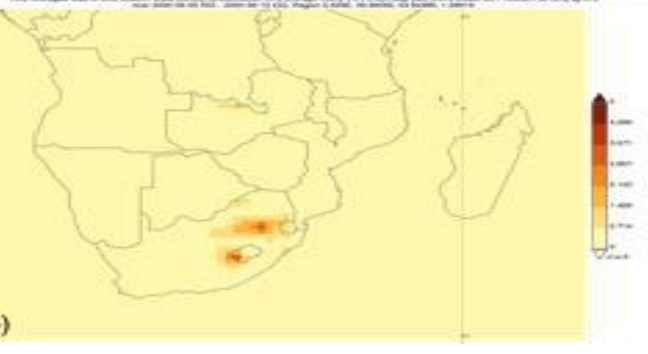

(d)

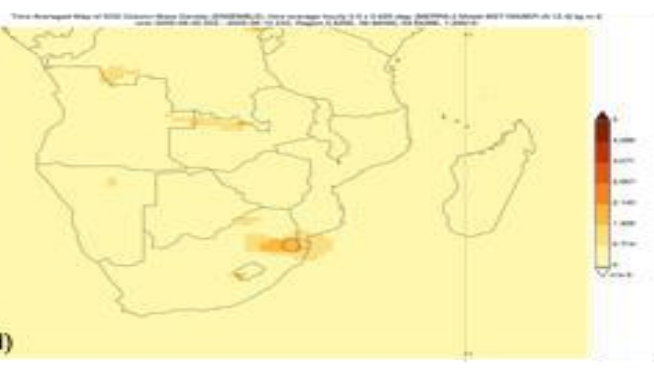

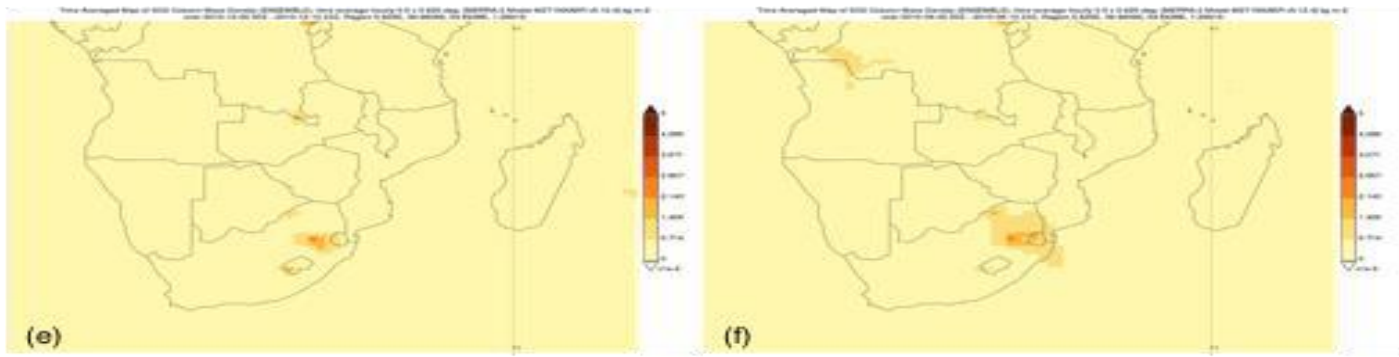

Fig. 9: $\mathrm{SO}_{2}$ concentrations between (a) summer and (b) winter respectively. Contours indicate increasing gas concentration and scales colour-coded in terms of concentration maxima. Source: MODIS onboard the Aqua satellite measurement (http://giovanni.gsfc.nasa.gov/giovanni/).

Similarly, we can show another common gas pollutant $\mathrm{NO}_{x}$ (herein $\mathrm{NO}_{2}$ ) to compare with the $\mathrm{SO}_{2}$ (Fig. 10). $\mathrm{NO}_{\mathrm{x}}$ is an important primary pollutant produced from anthropogenic and natural sources (e.g. fossil fuel combustion, BB, soil bacteria, lightning, oxidation of ammonia, mobile transport and other heavy machinery).While $\mathrm{SO}_{2}$ is from the MODIS-on-board the Aqua satellite measurement, $\mathrm{NO}_{\mathrm{x}}$ is a snap shot from satellite imagery in 2006.Again hot spots (column density order of $10^{16} \mathrm{~mol} / \mathrm{cm}^{2}$ ) for $\mathrm{NO}_{2}$ are observed over the Highveld and Angola-DRC; concentration patterns show how emissions spread to other areas from the source locations.

\section{(c) Carbon monoxide}

Next we show the spatial distribution of CO (Fig. 11) also from the NASA's Giovanni database. The concentration increases (more reddish) in the top-left corner (west) into the South Atlantic Ocean, but declines towards the east. Again concentration decreases towards the south. While the pattern is similar throughout, the summer of 2005 (Fig. 11(a)) has low CO concentration than other panels. However, the summer of 2010 (Fig. 11(c)) shows more wide emission coverage and some isolated hotspots over Madagascar.

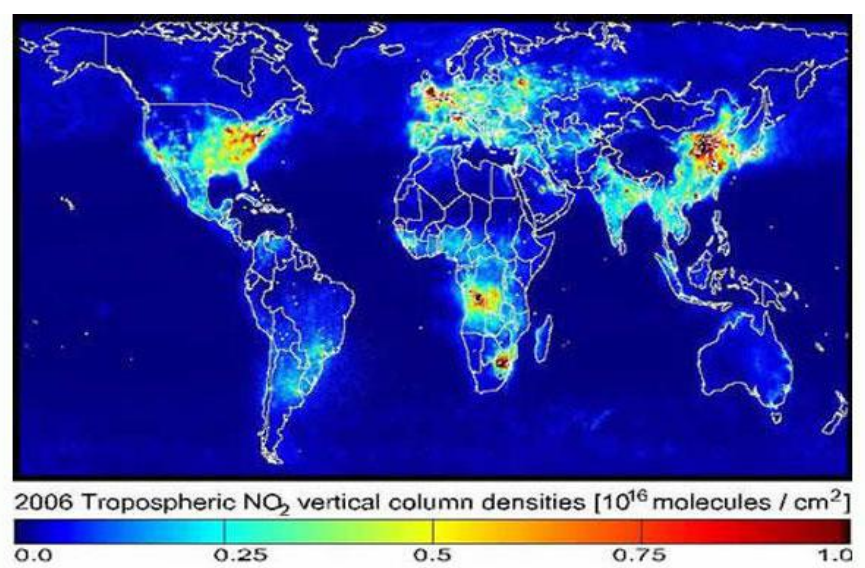

Fig. 10: Satellite images of tropospheric nitrogen dioxide $\left(\mathrm{NO}_{2}\right)$, 2006. There are high possible chances of transboundary pollution from South Africa and Angola into other countries. (Source:

http://www.learner.org/courses/envsci/unit/text.php?).

It is also worth noting that concentrations increase mostly over the BB areas (tropical central) than anthropogenicdominated regions. One distinct difference between the spatial distribution of the emissions in dust and COis that gases are more spread than aerosols. 
(a)

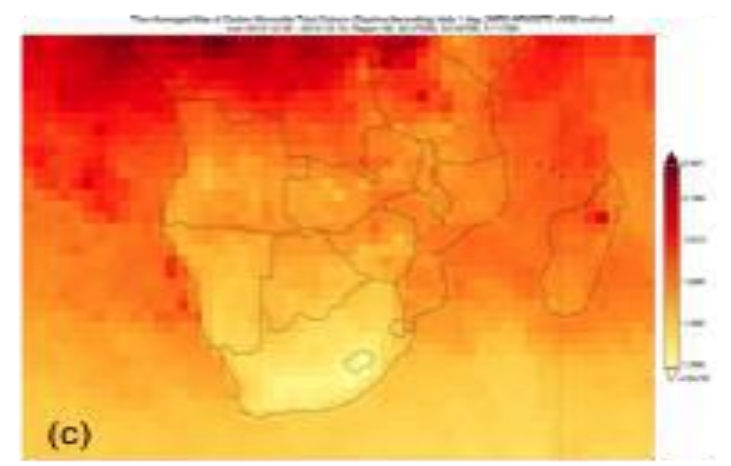

(b)

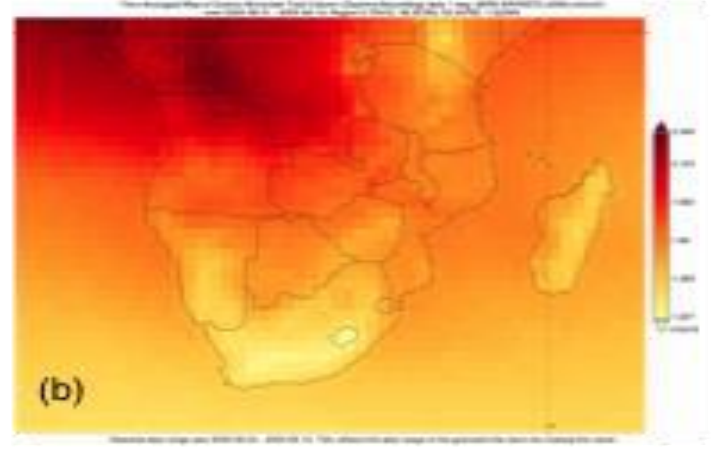

(d)

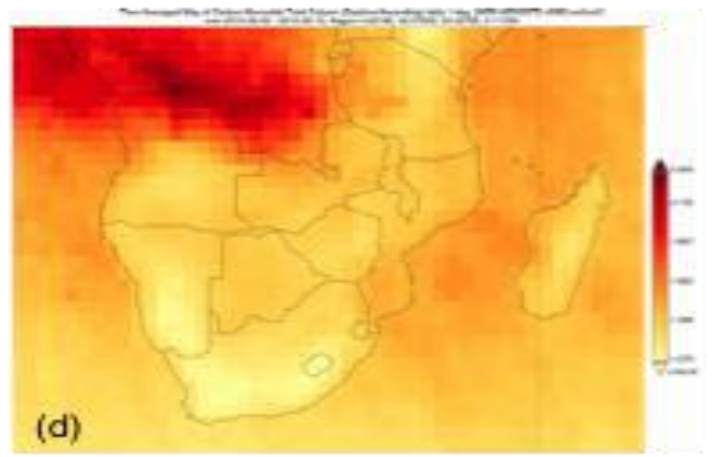

Fig. 11: COconcentrations between (a) summer and (b) winter respectively. Contours indicate increasing gas concentration and scales colour-coded in terms of concentration maxima. Source: MODIS onboard the Aqua satellite measurement (http://giovanni.gsfc.nasa.gov/giovanni/).

\subsection{Meteorology-chemistry interactions and influences} The atmosphere over southern Africa has unique meteorological and chemical characteristics that influence pollution transport and climate forcing (Garstang et al., 1996). Emission distribution is strongly influenced by the transport dynamics and air masses that prevail over most of the time (Kirkman et al., 2000). These circulation systems and transport pathways play vital roles in the local meteorology. For example, the frequent highpressure systems act as 'accumulation' mechanisms for trace gas and aerosols associated with haze layers and the westerly wave passages are responsible for the 'clean out' signatures (Stein et al., 2003). There is an indication that emissions have increased over the years, more pronounced during summer, although sometimes during winter (e.g. in 2005 there was a substantial increase in wind speeds).

Consequently there is a decline in precipitation with very little or no rainfall over the coastal areas. Temperatures along the west coast (between 2005 and 2010) appear to be cool in summer and become cooler in winters. It would of interest to try to understand all potential climate controls as highlighted earlier. Satellite images indicate more cloud coverage in summer, correlating with the rise in dust aerosols (more aerosols enhance the chance of cloud formation because they act as sites for developments). However, more clouds (precipitation) may result in pollution washout from the atmosphere, leading to pollution removal (wet deposition), whereas strong winds can also carry out pollution (dry deposition) from the atmosphere or away from the source. Urban pollution can enhance down welling radiation during clear nights and lead to increase in night-time minimum temperatures when warm air is mixed from aloft because of radiative destabilization (Knippertz et al., 2015). However, these kinds of interactions between weather parameters and chemistry are cyclic between the seasons. We also show temporal emission distribution for dust, $\mathrm{SO}_{2}$ and $\mathrm{CO}_{2}$ concentrations from 2000 through 2010 (Fig. 12).The trends show fluctuating patterns in pollutant concentrations across all the species. As expected, $\mathrm{CO}$ has the highest concentration than $\mathrm{SO}_{2}$ and dust. Global pollutants' emissions increase mainly driven by the demand for energy and transportation. As highlighted earlier, the changing meteorological patterns and seasonal human activities play vital roles in pollution levels. For instance the summer winds in 2000 show wind divergence over the Mpumalanga Highveld while the winter $\mathrm{SO}_{2}$ concentration appear to be spread in all directions but mostly directed towards the Mozambique coastal areas. 

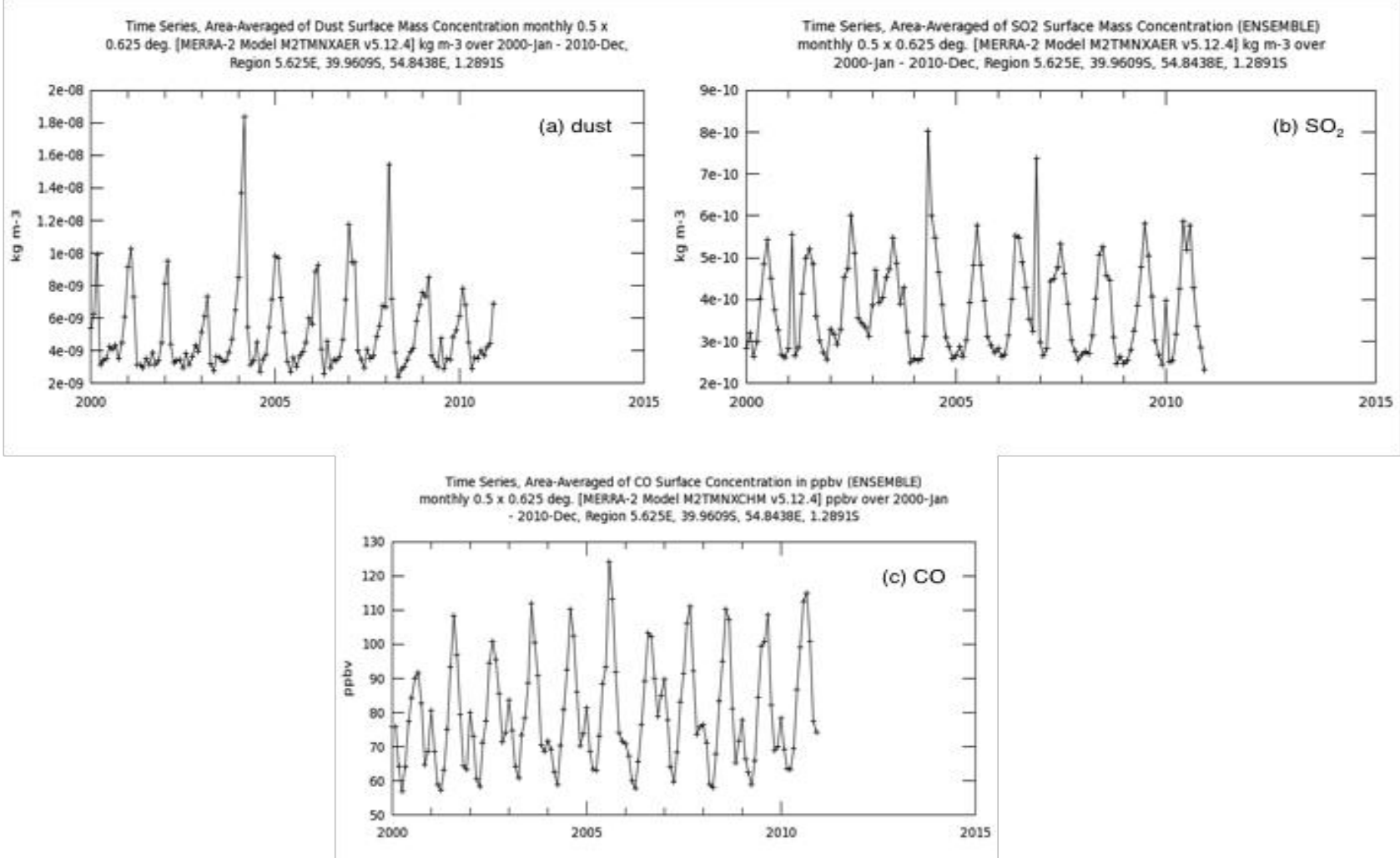

Fig. 12: Temporal distribution of (a) dust, (b) $\mathrm{SO}_{2}$ and (c) $\mathrm{CO}_{2}$ concentrations between 2000 until 2010 over southern Africa. Source: MODIS-on-board the Aqua satellite measurement (http://giovanni.gsfc.nasa.gov/giovanni/).

Common air circulations during winter (mostly westerly) also have the potential to carry the $\mathrm{SO}_{2}$ emission observed over the highland and further distribute it across. Between 2005 and 2010, wind patterns become more intense in summer, this could possibly scatter emissions further. Sulphate aerosols can also act as sites for cloud formation (cloud condensation nuclei [CCN]), althoughclouds formed around these compounds have varying radiative properties than other CCN. Increases in sulphate abundance may lead to more clouds or increase cloud albedo, and cause a net reduction in solar radiation reaching the earth surface (AQRS, 2001).An increase in the rainfall intensity in summer would imply more pollution washout from the atmosphere, especially in the proximity of polluting areas. On the other hand, frequent winds in winter increase likelihood of pollution transport and/or result in the build up of pollution (haze) above. This can alter radiation budget (depending on the intensity of absorbing or scattering aerosols present), or impact on cloud microphysical properties.

\section{CONCLUSION}

Southern Africa is characterized by the tropical and subtropical climatic conditions with great influence from the adjacent oceans, as well as the common air circulations. Since the late $20^{\text {th }}$ Century, the sub-continent has transformed from a rural to a complex society and has made great strides towards industrialisation, urbanisation, and economic development (Simukanga et al., 2003). These changes, compounded with population growth, brought about environmental problems virtually nonexistent in the past. Owing to different major pollutant sources, the region has experienced a considerable change recently and is recognised as a major source of pollutants (Wiston, 2016). Emissions exhibit a mixture of large quantities of aerosols and gases from BB, domestic fires, fossil fuel sources [automobiles and industries], construction, manufacturing and Aeolian dust.

While the SH summer is often characterized with more cloud coverage and wetness, winter is characterized with common air masses blowing over land. It is quite clear that pollution can influence the AQ composition over a given location. Consequently, some of the areas experiencing high levels of air pollution are the most populous and/or capital cities. Although there might not be national AQ problems on record, a number of air pollution conditions exist where severe AQ problems are likely to occur; examples being locations within active BB and high anthropogenic emissions. Vast amount of pollutants can be transported over long distances, impacting other areas downwind or those initially not in the vicinity of emitting sources. Under these conditions, humans are often exposed to high levels of pollution, which is not always monitored and sometimes exceed 
threshold limits (Wiston, 2017). Bad AQ cannegatively impact human health and may lead to respiratory problems such as heart failure, asthma, cardiac arrests, congestive heart failure and eye irritations. Anthropogenic and human-induced BB emissions increase mostly in winter when industrial activities are in operation and more vegetation burnt for various purposes. On the other hand, natural emissions are generated and fluctuate throughout the year.It is worth noting that southern African pollution plays a significant role on the weather and regional air quality composition.

\section{REFERENCES}

[1] Andreae, M. O., 1996. Raising dust in the greenhouse effect.Nature380, 389-390 (04 April 1996). doi: $10.1038 / 380389 \mathrm{a} 0$.

[2] Andreae, M. O., Atlas, E., Cachier, H., Cofer, W. R., Harris, G. W., Helas, G., Koppman, R., Lacaux, J., Ward, D. E., 1996. Trace gas and aerosol emissions from savanna fires, J. S. Levine (ed.), Biomass Burning and Global Change, MIT Press, Cambridge, 278-294.

[3] Air Quality Expert Group (AQEG), 2007. Air Quality and Climate Change: A UK Perspective. URL: https://ukair.defra.gov.uk/assets/documents/reports/aqeg/fullr eport.pdf.

[4] Air Quality Research Subcommittee (AQRS) of the Committee on Environment and Natural Resources CENR.April, 2001.

[5] Benkovitz, C. M., 1996. Global gridded inventories for anthropogenic emissions of sulphur and nitrogen, Journal of Geophysical Research, Vol.101, pg. 11.

[6] Bigg, G., 2003. The Oceans and Climate. Cambridge University Press.

[7] Chanda D.M.M., 2014. Lusaka City Chaos.Times of Zambia.Nov 19. Retrieved from (http//http://www.times.co.zm/?p=42940)

[8] Chédin, A., Serrar, S., Scott, N. A., Pierangelo, C., and Ciais, P.: Impact of tropical biomass burning emissions on the diurnal cycle of upper tropospheric $\mathrm{CO}_{2}$ retrieved from NOAA 10 satellite observations, J. Geophys. Res. Atmos., 110, D11309, doi:10.1029/2004JD005540, 2005.

[9] Crutzen, P. J., Andreae, M. O., 1990. Biomass Burning in the Tropics: Impact on Atmospheric Chemistry and Biogeochemical Cycles. Science. Vol. 250. No. 4988. pp. 1669-1678. doi:10.1126/science/250.4988.1669.

[10]DEA, 2014. Chapter 12: Energy. URL: DEA__Main_doc_-_Chapter_12_ZnNWB.pdf

[11]Eck et al., 2003. Variability of biomass burning aerosol optical characteristics in southern Africa during the SAFARI 2000 dry season campaign and a comparison of single scattering albedo estimates from radiometric measurements. J. Geophys. Res., 108(D13), 8477, doi: 10.29/2002JD002321, 2003.

[12] Food and Agricultural organization (FAO) of the United Nations, 2014. Chapter 4: The Influence of El Niño on the Global Agricultural Areas. URL: http://www.fao.org/3/a-i4251e.pdf.

[13] Garstang, M., Tyson, P. D., Swap, R., Edwards, M., Kallberg, P., Lindesay, J. A., 1996. Horizontal and vertical transport of air over southern Africa. J. Geophys. Res., Vol. 101. No. D19. pp. 23,72123,736. American Geophysical Union., doi:10.1029/95JD00844.

[14] Giannini, A., 2010.The Influence of Sea Surface Temperatures on African Climate. URL: https://www.ecmwf.int/sites/default/files/elibrary/20 12/9554-influence-sea-surface-temperatures-africanclimate.pdf.

[15] Hudson, D. A., Jones, R. G., 2002.Regional Climate Model Simulations of Present-day and future climate of southern Africa. Met Office.

[16]IPCC, 2007. IPCC Fourth Asssessment Report: Climate Change 2007. Human and Natural Drivers of Climate Change. URL: https://www.ipcc.ch/publications_and_data/ar4/wg1/ en/spmsspm-human-and.html.

[17]Jhun, I., Coul, B. A., Schwartz, J., Hubbell, B., Koutrakis, P., 2015. The impact of weather changes on air quality and health in the United States in 1994-2012. Environ. Res. Lett. $10 \quad$ (2015) 084009,doi:10.1088/1748-9326/10/8/084009.

[18] Kgabi, N. A., 2012. Air Quality policy and scientific research in southern Africa. WIT Transactions on Ecology and Environemnt. 01/2012; 157:151-163., doi:10.2495/AIR120141.

[19] Kirkman, G.A., Piketh, S.J., Andreae, M.O., Annegarn, H.J.,Helas, G., 2000. Distribution of aerosols, ozone and carbon monoxide over southern Africa.South African Journal of Science96, 423431.

[20] Knippertz et al., 2015.The possible role of local air pollution in climate change in West Africa.Nature Climate Change. Vol. 5., doi: 10.1038/NCLIMATE2727. www.nature.com/natureclimatechange

[21]Li, J., Pósfai, M., Hobbs, P. V., Busek, P. R., 2003. Individual aerosol particles from biomass burning in southern Africa: 2. Compositions and aging of inorganic particles. J. Geophys. Res., 108(D13), 8484, doi:10.1029/2002JD002310, 2003.

[22]Liousse, C., et al., 2010. Western African aerosols modelling with updated biomass burning emission 
inventories in the frame of the AMMA-IDAF program. Atmos. Chem. Phys. Discuss., 10, 73477382, 2010. $\quad$ www.atmos-chem-physdiscuss.net/10/7347/2010/

[23] Magi, B. I., 2009. Chemical apportionment of southern African aerosol mass and optical depth.Atmos. Chem. Phys., 9, 7643-7655, 2009. www.atmos-chem-phys.net/9/7643/2009/

[24] Matsueda, H., Taguchi, S., Inoue, H. Y., Ishii, M., 2002. A large impact of tropical biomass burning on $\mathrm{CO}$ and $\mathrm{CO} 2$ in the upper troposphere. Science in China (Series C). Vol. 45 Supp. pp. 116-125.

[25] Meter, S, Formenti, F., Piketh, S.J., Annegarn, H.J.,Kneen, M.A., 1999. PIXE investigation of aerosol composition over the Zambian copperbelt, Nuclear Instrument and Methods in Physics B, 150, pgs 433-438.

[26] Nicholson, S. E., Entekhabi, D., 1987. Rainfall variability in equatorial southern Africa: Relationship with sea surface temperature along the southwest coast of Africa. J. Climate Appl.Meteor., 26, 561-578.

[27] Nicholson, S. E., 2013. The West African Sahel: A Review of Recent Studies on the Rainfall Regime and its Interannual Variability.ISRN Meteorology. Vol. 2013, Article ID 453521.http://dx.doi.org/10.1155/2013/453521

[28] Obasi, O. P. G., 2001. The Impacts of ENSO in Africa.World Meteorological Organization. Geneva, Switzerland.

[29] Pachauri, R, K., 2007. Climate Change Synthesis Report.Summary of Policy makers.92-9169-122-4, p37.

[30] Piketh, S.J., Annegarn, H.J.,Kneen, M.A., 1996. Regional scale impacts of biomass burning emissions over southern Africa, in J.S. Levine (ed.). Biomass Burning and Global Change, MIT Press, Cambridge, pgs 320-326.

[31] Piketh, S. J., Formenti, P., Annegarm, H. J., Tyson, P. D. 1999. Industrial Aerosol characterisation at a remote site in South Africa. Nuclear Instruments and Methods in Physical Research Section B: Beam interactions with Materials and Atoms. Vol. 150, Issue 1-4.http://dx.doi.org/10.1016/SO168583X(98)00985-9

[32] Piketh, S. J., Swap, R. J., Maenhaut, W., Annegarn, H. J., Formenti, P., 2002. Chemical evidence of long-range atmospheric transport over southern Africa.Journal of Geophysical Research. Vol. 107. No. D24, 4817.doi:10.1029/2002JD002056, 2002.

[33] Piketh, S. J., Walton, N. M., 2004. Characteristics of Atmospheric Transport of Air Pollution for Africa.The handbook of Environmental Chemistry.

Vol. 4, Part G (2004): 173-195. Doi
$10.1007 / \mathrm{b} 94527$.

[34]Road Management \& Engineering Journal, 1998. URL:

http://www.usroads.com/journals/rmej/9811/rm9811 01.htm

[35]Schefub, E., Schouten, S., Schneider, R., 2005. Climatic controls on central African hydrology during the past 200, 000 years. Nature Publishing Group. Vol. 437. doi:10.1038/nature03945.

[36]Scholes, R. J., Archibald, S., von Maltitz, G., 2011. Emissions from fire in Sub-Saharan Africa: the Magnitude of Sources, Their Variability and Uncertainty. Global Environmental Research. Vol. 5. $\quad$ pp. 53-63. re.indiaenvironmentportal.org.in/files/.../emissions $\% 20$ from\%20fire....

[37]Scholes, R. J., Kendall, J., Justice, C. O., 1996b. The quantity of biomass burned in southern Africa. J. Geophys. Res., 101 (D19), pp. 23,66723,676,October 1996.

[38] Schwela, D., 2012.Review of Urban Air Quality in Sub- Saharan African Region, Air Quality Profile of SSA Countries, pg. 6.

[39]Seinfeld, J. H., Pandis, S. N., 2006. Atmospheric Chemistry and Physics: From Air Pollution to Climate Change. $2^{\text {nd }}$ ed. John Wiley \& Sons Inc.

[40] Shugart, H. H., Macko, S, A., Lesole, P., Szuba, T. A., Mukelabai, M. M., Dowty, P., Swap, R. J., 2004. The SAFARI 2000 -Kalahari Transect Wet Season Campagin of year 2000. Global Change Biology. Vol. 10, pp. 273-280. doi: 10.1111/j.15298817.2003.00732.

[41] Simukanga, S., Hicks W.K.,Feresu S., Kuylenstierna, J. C. I., 2003. The Air Pollution Information Network For Africa (Apina): Activities Promoting Regional Co-Operation On Air Pollution Issues In Southern Africa.

[42] Siversten, B., Matar, C. and Pereira., L.M.R., 1995. Sulphur emissions and transfrontier air pollution in southern Africa, SADC E LMS, Report 35, pg4-6.

[43] Skaeda, N., Wood, R., Rasch, P. J., 2011. Direct and semidirect aerosol effects of southern African biomass burning aerosol, J. Geophys. Res., 116, D12205, doi:10.1029/2010JD015540.

[44] Smith, S. J., Pitcher, H., Wigley, T. M. L., 2001.Global and regional anthropogenic sulphur dioxide emissions. Global and Planetary Change. Vol. 29, Issue 1-2.pp 99-119. Elservier. http://dx.doi.org/10.1016/S0921-8181(00)00057-6.

[45] Stein et al., 2003. Haze layer characterization and associated meteorological controls along the eastern 
coastal region of southern Africa. J. Geophys. Res., 108(D13), 8506, doi:10.1029/2002/JD003237.

[46] Swap et al., 2002. The Southern African Regional Science Initiative (SAFARI 2000): overview of the dry season field campaign. South African Journal of Science 98, March/April 2002.

[47] Swap et al., 2003. Africa burning: A thematic analysis of the southern African Regional Science Initiative (SAFARI 2000). Journal of Geophysical Research.Vol. 108. No. D13. 8465. doi: 10.1029/2003JD003747.

[48] Torres, O., Chen, Z., Jethva, H., Ahn, C., Freitas, S. R., Bhartia, P. K., 2010.OMI and MODIS observations of the anomalous 2008-2009 Southern Hemisphere biomass seasons. Atmos. Chem. Phys., $10, \quad 3505-3513,2010 . \quad$ www.atmos-chemphys.net/10/3505/2010/

[49] Tummon, F., Solomon, F., Liousse, C., Tadros, M., 2010. Simulation of the direct and semidirect aerosol effects on the southern Africa regional climate during the biomass burning season. Journal of Geophysical Research. Vol. 115. D1906. doi:10.1029/2009JD013738.

[50] Tyson, P. D., Garstang, M., Swap, R., Kallberg, P., Edwards, M., 1996a. An Air Transport Climatology for Subtropical southern Africa. International Journal of Climatology. Vol. 16, pp. 265-291. American Meteorological Society.

[51] Tyson, P. D., Garstang, M., Swap, R., 1996b. LargeScale recirculation of Air over Southern Africa.Journal of Applied Meteorology. Vol. 35. pp. 2218-2236. A. M. S.

[52] United States Environments Protection Agency (USEPA). 2003, Air Quality Index, A Good Air Quality and Year Health, pg2.

[53] United States Environmental Protection Agency (USEPA). 2009. Endangerment and Cause or Contribute Findings for Green House Gasses.Section 202 (a).pg 6 .

[54] Wells, R.B., Lloyd, S.M., Turner, C.R., 1996. National air pollution source inventory -Inventory of scheduled processes, Air pollution and its impacts on the South African Highveld, Environmental Scientific Association, Cleveland, pg 3.

[55] World Meteorological Organization (WMO), 2014.El Niño Southern Oscillation. Observation. URL:

http://www.wmo.int/pages/prog/wcp/wcasp/docume nts/JN142122_WMO1145_EN_web.pdf.

[56] Wiston, M. 2016. Regional modelling of air quality and aerosol-interactions over southern Africa: Impact of aerosols and regional-scale meteorology. PhD Thesis. The University of Manchester.
[57]Wiston, M. 2017.Status of Air Pollution in Botswana and Significance to Air Quality and Human Health. Journal of Health and Pollution: September 2017, Vol. 7, No. 15, pp. 817.https://doi.org/10.5696/2156-9614-7.15.8

[58]Zakey, A., Solmon, F., Giorgi, F., 2006: Implementation and testing of a desert dust module in a regional implementation and testing of a desert dust module in a regional climate model. Atmos. Chem. Phys.,6, 4687-4704.

[59]Zunckel, M., Robertson, L., Tyson, P. D., Rodhe, H., 2000.Modelled transport and deposition of sulphur over Southern Africa. Atmospheric Environment. Vol. 34, Issue 17, 2000.https://doi.org/10.1016/S1352-2310(99)004951 